\title{
RÖVIDEN A FEJLŐDÉSI DISZPRAXIÁVAL KAPCSOLATOS KÉRDÉSEKRŐL
}

\author{
Szerzők: \\ Pető Ildikó (PhD.) \\ Debreceni Egyetem (Magyarország) \\ Első szerző e-mail címe: \\ peto.ildiko@ped.unideb.hu
}

\author{
Lektorok: \\ Németh Nóra Veronika(PhD.) \\ Debreceni Egyetem (Magyarország) \\ Mező Katalin (PhD.) \\ Debreceni Egyetem (Magyarország
}

Pető I. (2020). Röviden a fejlődési diszpraxiával kapcsolatos kérdésekről. Különleges Bánásmód, 6. (2). 105116. DOI $\underline{10.18458 / K B .2020 .2 .105}$

\begin{abstract}
Absztrakt
A diszpraxia a laikus embereknek, de még a szakemberek egy részének is rejtély több szempontból is. Kérdésként merül fel, hogy mi a diszpraxia, van-e köze a fejlődési koordinációs rendellenességhez és más hasonló állapotokhoz, hány gyereket érint, hogyan lehet felismerni és diagnosztizálni, és hogyan lehet javítani az állapoton. Jelen írás a kérdések alapján próbál rövid áttekintést adni a fejlődési diszpraxiáról mint állapotról. Foglalkozik a felmerülő terminológiákkal, az állapotnak a különböző képességterületekre gyakorolt hatásával és a társuló állapotokkal.
\end{abstract}

Kulcsszavak: gyógypedagógia, fejlődési diszpraxia, mozgáskoordinációs zavar Diszciplina: gyógypedagógia

\section{Abstract}

\section{BRIEFLY ABOUT ISSUES RELATED TO DEVELOPMENTAL DYSPRAXIA}

Dyspraxia is hardly known to many people at all, but it is also less known for professionals as well. The questions are that - what does dyspraxia mean, is it related to developmental coordination disorder and another similar status. How many children are affected, how can it be recognized and diagnosed and how should it be managed? This paper attempts to provide a brief overview of developmental dyspraxia based on the questions. It deals with emerging terminologies, the impact of a state on different areas of ability, and associated states.

Keywords: special needs education, developmental dyspraxia, developmental coordination disorder Disciplines: special needs education 


\section{Miről lesz szó?}

„A fiam, Máté két és fél éves volt, amikor már nagyon aggasztott, hogy a fejlődés minden lépése jócskán késve érkezik el nála. Sokkal később kezdett el forogni, felülni, járni, a tárgyakkal manipulálni, gond volt az etetésével, emiatt sokat sírtam. Már korán elkezdtünk szakemberekhez menni, orvoshoz, gyógytornászhoz, gyógypedagógushoz, konduktorhoz, pszichológushoz. Rákot, gyermekkori vagy magzati stroke-t, agyi bénulást, figyelemzavart, alacsony intellektust és sok egyéb szindrómát és rendellenességet kaptunk diagnózisként, de vagy kiderült, hogy nem az, vagy mi éreztük, hogy nem lehet az az oka a fiam elmaradásának. Előbb a harmadik gyógypedagógus, aztán egy gyermekneurológus, aki már a második volt, akinél jártunk, vetette fel azt, hogy fejlődési diszpraxiáról lehet szó. Közben több értékes év eltelt.” (egy szülö)

Amikor egy gyermeknél valamilyen fejlődési rendellenességet, eltérést vagy elmaradást diagnosztizálnak, a szülőben sok érzelem kavaroghat: sokk, rémület, tanácstalanság, szomorúság és megkönnyebbülés. Ugyanakkor azonnal meg szeretné tudni, hogy miként segíthet legjobban gyermekének, és hogyan tervezze meg az elkövetkező éveket. Arra is kíváncsi lehet, hogy a családja hogyan fog megbirkózni az eltérő fejlődéssel, hogyan alakul majd a kapcsolata a testvéreivel. Sok szüló bűntudatot és haragot érez a gyermek állapota miatt, ami akkor is igaz, ha a gyermek nehézségeit a diszpraxia okozza, amelyről napjainkban még Magyarországon keveset beszél-nek a szakemberek és igen ritkán fogalmazzák meg diagnózisként.

Amikor egy szülő meghallja, hogy gyermeke esetleg diszpraxiával küzd, a „természetes” negatív érzések mellett sok kérdőjel is el kezd kavarogni benne, föleg, mert nem tudja, hogy mit is jelent. Annak ellenére, hogy a diszpraxia meglehetôsen gyakori, sokan soha nem, de a szakemberek is csak ritkán és keveset hallottak róla.

\section{Mi a diszpraxia?}

\section{Mi a fejlődési diszpraxia?}

A „praxia” szó cselekvéssorok tervezését, irányítását jelenti, ami egy meghatározott cél, feladat érdekében történik. A cselekvéssorok, ezek tervezése és irányítása tanulási folyamat eredményeként alakul ki, jellemzően sok gyakorlás szükséges hozzá. A praxia a saját test és a környezet kölcsönhatásában megszerzett és elsajátított mozgás megfelelő alkalmazása, ami magába foglalja, hogy

- a mozgássorok helyes időrendben követik egymást,

- a felesleges együttmozgások kiiktatásra kerülnek,

- a testséma és téri tájékozódás pontos.

A praxia sérülésével kapcsolatban első lépésben két fogalmat, az apraxiát és a diszparxiát kell elkülöníteni. Az apraxia a praxis, tehát a gyakorlat (teljes) hiányát, valaminek a kivitelezési képtelenségét jelenti, míg a disz-praxia egy atipikus fejlődésre utal. A fogalmak elkülönítésében fontos szempont a zavar kialakulásának, megjelenésének az ideje, időpontja, aminek alapján beszélhetünk szerzett és fejlődési diszpraxiáról (Dewey, 1995).

A praxia szerzett zavara, a mozgássorok kivitelezésének a nehézsége nagy valószínúséggel kapcsolható valamilyen idóponthoz, eseményhez, pl. agyvérzéshez, koponyatraumához, agyi érkatasztrófához, tumorhoz, a központi idegrendszert érintő fertőzéshez, degeneratív betegségekhez, s egy addig tipikusan fejlődött és múködő rendszerre hat negatívan. A fejlődési diszpraxia ezzel szemben már korai életkorban mutat tüneteket, még akkor is, ha azokat csak utólag ismerjük fel, s a zavar hat más területek fejlődésére és integrációjára is. 
A diszpraxiás állapotot még a magyar nyelvben is több néven szokták említeni, beszélnek fejlödési koordinációs rendellenességről, motoros tanulási nehézségről, motoros tervezési nehézségrôl, beszéd apraxiáról, stb. A terminológiai sokszínúség csak fokozza a bizonytalanságot, ha megnézzük az angol elnevezéseket is. A két leggyakrabban használt szakkifejezés a „developmental coordination disorder” (DCD, fejlődési koordinációs zavar) és a „developmental dyspraxia” (DD, fejlődési diszpraxia) mellett meg kell említeni a „developmental apraxia"-t (DA, fejlődési apraxia) is (Polajko, Fox és Missiuna, 1995, Dewey, 1995).

A developmental coordination disorder (DCD) és developmental dyspraxia (DD) kifejezések nem véletlenül alakultak ki, az egymáshoz való viszonyukat egymástól eltérően értelmezik a kutatók is. Vannak, akik a két fogalmat (DCD és DD) egymással felcserél-hetônek tartják (I.1.), míg pl. Addy (2003, In: Roy, D. \& Dock, C.,2013) úgy gondolja, hogy a DCD egy olyan gyújtőfogalom, amely minden motoros koordinációs zavart magában foglal, s ezen zavarok egyike a diszpraxia. Addy szerint egy szándékos mozgásfolyamat létrejöttéhez három különböző szintű idegrendszeri aktivitásra van szükség. Először a cselekvés koncepciójának, gondolatának kell megszületnie, majd az így létrejött belső reprezentációt követi a mozgástervezés folyamata. Harmadik lépésként a végrehajtás következik, s csak ez utóbbinak van köze a mozgáskoordinációhoz.

Vannak azonban olyan szakemberek, akik gyújtőfogalomnak a fejlődési diszpraxiát tekintik (Henderson, Henderson, 2003; Blank et al., 2012; Gibss, Appleton és Appleton, 2007), ahova minden olyan mozgásfejlődési zavart sorolnak, amelyekre a motoros koordináció, a mozgástervező és szervezô, és/vagy végrehajtó képességének jelentős zavara jellemző, de a vizsgálatok nem mutatnak jelentôs neurológiai eltéréseket (pl. CP, izomdisztrófia, stb.). A diszpraxia nem izomgyengeség vagy nem az alacsony intelligencia jele, annak ellenére, hogy a háttérben az idegrendszer nem megfelelő múködése áll. Agyi eredetű állapot, amely megnehezíti a mozgás megtervezését és koordinálását megnehezítve a gyermek mindennapi mozgásos feladatainak a széles skáláját, pl. az étkezés, a fogmosás, a nadrág felvételét, az iskolatáskába való bepakolást, vagy a ceruza megfogását is. Befolyásolja a nagymozgásos készségek fejlődését, pl. mint a járás vagy az ugrás, és a finommotorikus képességeket is, pl. a kézmozgásokat, amelyek az íráshoz szüksé-gesek, valamint a száj, ajkak és a nyelv mozgását a szavak helyes kiejtése során.

A diszpraxiás gyermekek ügyetlennek tűnnek, vagy olyannak, mint akik nincsenek ,szinkronban” a környezetükkel (I.2.). A környezettel való diszharmónia a szociális készségeket is befolyásolhatja, gyakran a diszpraxiával küzdő gyermekek éretlen módon viselkednek, annak ellenére, hogy jellemzôen átlagos vagy átlag feletti intelligenciájuk van.

A gyerekek nem nővik ki a diszpraxiát, de a különböző célzott terápiák és a folyamatosan kialakított és megtanult stratégiák segíthetnek, hogy felnőttként sikeresen élhessék az életüket. A gyerekek megtanulhatnak a problémával élni, a gyengeségeiket korrigálni, az erôsségeikre pedig építeni.

Samuel Orton a mozgáskoordináció fejlő-dési zavarát összefoglaló néven „abnormális ügyetlenségnek" nevezte el, ami nem volt indokolatlan, hiszen amit felületes szemlélőként is láthatunk egy diszpraxiás gyerekkel találkozva, az az, hogy lassan és ügyetlenül öltözködik, nekiütközik másokba, ügyetlenül bánik a hétköznapi eszközökkel is, összerendezetlenül fut, mozdulatai darabosak, kapkodónak tűnnek, gyakran célszerútlen cselekvéseket végez. Már a pejoratív és bántó „abnormális” jelző miatt egy új fogalmat használunk a mozgás zavarának esetünkben tárgyalt állapotára, a „fejlődési diszpraxiá"-t. De mielőtt Ayres alapján elkezdtük használni a „fejlődési diszpraxiát," az elmúlt évtizedekben gyors változások történtek a fogalomhasználatban. A hetvenes évektől konszenzus 
kezdett kialakulni a szakemberek között abban, hogy etiológia és tipológiai szempontból is fontos külön kezelni a fejlődési és a szerzett mozgáskoordinációs zavarokat, és többnyire az „,̈gyetlen gyermek" elnevezést használták. Nagy előrelépés volt, hogy Cermak és Ayres összefüggésbe hozta a dispraxiát a tanulási zavarok etiológiájával, s ebból kiindulva Cermak (1985 In: Miyahara és Möbs) a „motor weakness" vagy „psychomotor syndrome”, míg Ayres (1972; 1987 In: Szvatkó) a fejlődési diszpraxia kifejezést ajánlotta. Ayres szerint a fejlődési diszpraxia „az idegrendszer olyan funkciózavara, mely nehezíti a taktilis, néhol a vesztibuláris és a proprioceptív információk feldolgozását, melynek következtében a mozgástervezés képességét korlá-tozza" (Ayres, 2016: 138, In: Fehérné Kovács, Kas \& Sósné Pintye, é.n.). Értelmezve a meghatározást, Ayres a diszpraxiát mint a testhelyzetek utánzásának zavarát írja le, s azt feltételezi, hogy a diszpraxiás gyermeknek minden mozdulatot újra- és újra kell tervezni, mivel a mozdulatsorok nem automatizálódnak.

Ma már általánosan elfogadott a „fejlődési diszpraxiának" az az értelmezése, hogy a mozgáskoordináció fejlődési zavarát takarja, a szakemberek is szokták így emlegetni, azonban ebben az esetben hangsúlyos a kivitelezés zavara mellett a tervezés alacsony szintje is. E speciális mozgáskoordinációs zavar az életkornak megfeleló és jellemző napi tevékenységekben jelentkezik, a tevékenységek végrehajtásához szükséges finom- és nagymozgásos készségek, a fejlődésének, az elsajátításának és összehangolt kivitelezésének általában tartós, de nem súlyosbodó zavara.

A BNO-10 az F82 kóddal a „A motoros funkció specifikus fejlődési rendellenességei” néven jelöli az állapotot. A DSM-5 meghatározása szerint akkor kell beszélnünk róla, amikor a mozgáskoordinációs készségek elsajá-títása és kivitelezése lényegesen elmarad a személy biológiai kora, továbbá a készségek tanulására és használatára való lehetőség alapján elvárt szinttől, ami hatással van az iskolai tevékenységre és a mindennapokra; a korai életkorban jelenik meg és nem magyaráz-ható intellektuális képességzavarral (IKZ), vagy a mozgást érintő neurológiai sérüléssel. Mindenféle meghatározásban hangsúlyozzák, hogy a személy intelligenciája átlagos vagy átlag feletti. Sőt találhatunk olyan leírásokat a különböző szülőszervezetek vagy a diszpraxiával foglalkozó segítő szervezetek honlapján, miszerint a memóriájuk is átlag vagy átlag feletti, de ezt még nem bizonyították nagymintás vizsgálattal.

A fejlődési diszpraxia felismerésében kezdetben nehézséget jelentett, hogy a diszpraxiás gyermekek körében nagy számban fordulnak elő különböző tanulási és viselkedési zavarok is. De nem csak a múltban, hanem még napjainkban is nehéz az állapotok elkülönítése, ezért eleinte nagyobb hangsúlyt kapott a jelenség más fejlődési zavaroktól való elkülönítése.

\section{Milyen típusai vannak a fejlódési diszpra- xiának?}

A szakemberek és a diagnosztikus kézikönyvek a fejlődéses és a szerzett diszpraxiáknek alapvetően ugyanazt altípusként, a végtag diszpraxiát (limb dyspraxia), az orofaciális diszpraxiát (orofatial dyspraxia) és a verbális diszpraxiát (verbal dyspraxia), amelyeket egyszerúbben motoros, orális és verbális diszpraxiának nevezhetünk. A motoros diszpraxia esetében a teljes mozgásrepertoár ügyetlenebb, koordinálatlanabb, lassúbb vagy éppen kapkodó. Az orális diszpraxia (oromotoros diszpraxia) dominánsan a mimikai, az artikulációs mozgásokra korlátozódik, míg a verbális diszpraxia agyi eredetű jelentős artikulációs zavart jelent. A verbális diszpraxia esetében a beszédmozgások nehézkesek, ami befolyásolja a pontos artikulációt, a beszédmozgások következetes végrehajtását. Előfordulhat, hogy a gyermeknek a bonyolultabb beszédhangok ejtése gondot okoz, esetleg képtelen rá, de lehetséges, hogy egy szó következetesen 
ugyan-olyannak ejtése jelent nehézséget. A verbális diszpraxia mint kategória viszonylag elterjedt, és egyre többet vizsgált probléma a logopédiában. A három forma (végtag, orofaciális és verbális diszpraxia) külön-külön és egymás-sal kombinálva is előfordulhat (Huba, 2011; Dewey 1995).

A fejlődési diszpraxia tünetcsoportját a korábban, a szerzett diszpraxia mintájára két főcsoportba sorolták: ideomotoros ideátoros és diszpraxia. Az előbbi, az ideomotoros diszpraxia esetében a teljes cselekvési terv megtartott, azonban az egyes mozzanatok kivitelezése nem sikerül.

Megnehezíti az egylépéses mozgásos feladatok elvégzését, például a haj fésülését, a száj letörlését a kézfejjel, a kisgyerekeknél az integetést búcsúzáskor. Az ideátoros típus esetében az egyes mozdulatok egyedi kivitelezése sikerül, azonban ezek szekvenciákba szervezése zavart szenved. Az egyén az egyes mozzanatokat nem tudja úgy térben és időben tagolt logikus egységgé szervezni, hogy a kitűzött célját elérje.

A fentebb tárgyalt különböző szempontú ismertebb típusok mellett számos másfajtáról is lehet hallani, ami jelzi a probléma összetettségét és feltáratlanságát is (Dewey, 1995; Gibbs, Appleton, \& Appleton, (2007):

- konstruktív diszpraxia, ami testséma, orientációs és laterális dominancia zavart jelent

- téri diszpraxia (diszkinézia), ami a mozgásfolyamat utánzásának a nehezítettségét jelenti, a téri és az idői rendezés gyengeségét, testséma zavarát

- okuláris diszpraxia, ami a mozgó tárgy követésének a nehézsége,

- szerkezeti diszpraxia: megnehezíti a térbeli viszonyok és kapcsolatok megértését, pl. a geometriai rajzok másolása, valaminek a szétvagy összeszerelése, szerkezetek működtetése

A nehézség kiterjedhet egyes testrészekre (pl. az arcra, a kézre, a nyelvre, stb.), csak bizonyos tevékenységekre (pl. az öltözködésre, a téri tájékozódásra, stb.) vagy komplex cselekvéssorok végrehajtására („ügyetlen gyermek” szindróma).

Röviden összefoglalva a fejlődési diszpraxia állapotát, kiemelendó, hogy a szenzoros integráció zavarainak egyfajta megnyilvánulása (Ayres, 1995 In: Fehérné Kovács, Kas \& Sósné Pintye, é.n.), amikor ép mozgásrendszer ellenére a gyermek (vagy felnőtt) mozgásrepertoárja szúk, gyakran éri kisebb-nagyobb baleset, mozgásos játéka, tevékenysége fantáziátlan, testsémája fejletlen, viselkedése önállótlan.

\section{Milyen gyakori a fejlődési diszpraxia?}

Noha a diszpraxia nem olyan széles körben ismert és tárgyalt, mint más, a tanulást befolyásoló állapotok, mint például a diszlexia, úgy gondolják a szakemberek, hogy sokkal gyakoribb, mint az képzeljük. A gyermekeknek körülbelül 6-10\%-ánál, a lakosságnak 10\%-ánál jelentkeznek bizonyos diszpraxiás jelek, a 2\%-uknál a tünetek súlyosaknak tekinthetők (Barnhart, Davenport, Epps, \& Nordquist, 2003). A fiúkat kétszer-ötször gyakrabban érin-ti, mint a lányokat. (I.1., Gibbs, Appleton, \& Appleton, 2007).

A fejlődési koordinációs rendellenességnek (diszpraxia), mint egész életen át tartó idegrendszeri állapotnak a népességben való pontos aránya valójában még ismeretlen, mivel a rendellenességet nehéz felismerni és diagnosztizálni, a standardizált, megbízható tesztek, vizsgálóeljárások hiánya miatt. De biztosak lehetünk abban, hogy sok, tünettel rendelkező személyt soha nem fognak diagnosztizálni, ezért nevezhetjük „rejtett problémának” (Blank, Smits-Engelsman, Polatajko \& Wilson, 2012; Zwicker, Missiuna, Harris \& Boyd, 2012).

Vannak vizsgálatok, amelyek a családi halmozódást, az öröklődést, illetve a más állapotokkal való komorbiditást hangsúlyozzák. 


\section{Melyek a fejlődési diszpraxia tünetei?}

A kutatók még nem tudják, mi okozza a diszpraxia kialakulását. Vannak, akik úgy vélik, hogy a genetika játszik szerepet, vannak, akik azt gondolják, hogy a diszpraxia problémáját az idegsejtek okozhatják, amelyek az agyból az izmoknak adnak jelzéseket. Többen egyetértenek abban, hogy a koraszülött, alacsony születési súlyú vagy méhben alkoholnak kitett gyermekeknél nagyobb valószínúséggel alakul ki diszprapxia (I.3.).A diszpraxia néhány gyermeket súlyosabban érint, mint másokat. A megfigyelhetó jelek nem csak súlyosságukban különbözhetnek, hanem megjelenésükben is, amit tovább kombinál az, hogy az életkorral is változnak. Minden életkorban nehezíti a felismerést, hogy nincs egy olyan tünetlista, ami minden esetben megfigyelhető és segítene a diagnosztizálásban. Általában elmondható, hogy a tünetek már a korai életkorban jelentkeznek, csecsemókorban a gyermek szokatlanul nyugtalan, nyűgös lehet és nehéz az etetésük is. Lassan éri el a következő fejlődési mérföldkövet, például késve fordul át, fog és tart meg tárgyat a kezében, ügyetlenül dugja az öklét a szájába, a vártnál később kezd el mászni vagy önállóan járni.

Kisgyermekkorban nagyon maszatosan eszik, inkább az ujját használva kézzel eszik, mint villával vagy kanállal. Nem szeret és nem tud háromkerekú biciklin menni, de nem szereti a labdát, a labdázást sem. Kerüli az építójátékokkal való játékot, azt hogy valamit megkeressen a szobában, a játékpolcon. Nehéz és hosszú folyamat, mire leszokik a pelenkáról és egyedül vagy kevés segítséggel tudja használni a WC-t. Beszéd- és nyelvi fejlődése is elmarad a korosztályától, gyakori, hogy 2,5-3 éves koráig nem kezd el beszélni.

Közösségbe kerülve óvodás- majd kisiskolás korban, amikor a nap nagy részét sok ember között kell eltölteni, feltűnő, hogy gyakran neki ütközik másoknak, a bútoroknak, amit félreértelmezve agressziónak, durvaságnak tartanak. Ezért is nehezen tud más gyerekekkel játszani, játékot kezdeményezni vagy a kezde-ményezett kapcsolatot folytatni, fenntartani. Nehezen és csak késve tanul meg ugrálni, le-, fel-, átugrani, ami miatt kimarad a közös mozgásos játékokból, a közös udvari tevékenységekből, de testnevelés órán akár ki is nevetik. A tárgyakat ügyetlenül fogja meg, nehézkesen használja, gyakran leejti, leveri azokat, ami a gombok, a patentok és a cipzárok használatát is nehezíti. Értelemszerúen a ceruza megfogása, megtartása, a ceruzanyomaték nem megfelelő és a teljes grafomotoros tevé-kenység jelentősen elmarad az életkorától elvárhatótól. Jellemzően lassan beszél, nehezen vagy nem is tudja a beszédének a sebességét növelni, a hangerôt és a hangmagasságot változtatni. Érezhetô, hogy gondot jelent a gyermek számára, hogy elmagyarázza a szavak jelentését, nem tudja körül írni a szót, miközben ő maga megérti a körülírást, a magyarázatokat.

Felső tagozaton és a középiskolában, azaz a kisés nagykamaszkorban nehéz számára a kisebbnagyobb tárgyak egyik helyről a másikra történő mozgatása, például a társasjáték bábú-jával való lépegetés, a gyorsaságot igénylő kártyajátékok (pl. Dobble), s minden olyan játék és tevékenység, amelyik szem-kéz-koordinációt igényelnek. Ennek alapján nyilvánvaló, hogy a ceruza megfogása, megtartása, a betúk alakítása és összekapcsolása nehézkes, csak lassú tempóban halad az írással. Írás közben, amire a pedagógusok gyakran panaszkodnak, hogy sokat izeg-mozog, csúszkál a széken, lefekszik a padra a gyenge izomtónusa miatt, a tanórán elhangzó információk, utasítások követése kihívás a számára, ezért nem tudja azokat megjegyezni és emiatt a végrehajtása közben felidézni. Továbbra sem szereti a fizikai aktivitást igénylő tevékenységeket, kerüli a sportot, szenved a testnevelés óráktól, még a kerékpározást is kerüli. Továbbra is hajlamos elesni, megbotlani, másokba, dologba beleütközni, nekimenni. Az önállóság mint elvárás vele szemben egyre erőteljesebb, ezért egyre feltűnőbb lehet, hogy elfelejti, hogy hol kell keresnie a dolgokat (hol van a helye, hol hagyta, stb.), 
elveszítheti az iskolai felszerelését, a bérletét, a sapkáját. Nem csak a kortárs kapcsolataiban okozhat konfliktust, meg nem értést, hogy nehezen értelmezi mások nonverbális kommunikációs jeleit, illetve folyamatosan beszél, de azok nem mindig adekvátak, gyakori, hogy ugyanazt ismételgeti.

A gyermek, a fiatal állapota javulhat a folyamatosan végzett célzott terápiák hatására az izomtónus szabályozása és a koordináció finomodhat.

\section{Milyen készségeket befolyásol a fejlődési diszpraxia?}

A diszpraxia következményeit, hogy milyen területekre van hatással, jobban látjuk a készségek oldaláról tekintve. A mindennapos tevékenységek jellemzően nehézséget jelentenek, megnehezítheti a függetlenséghez szükséges mindennapi feladatok elsajátítását és kivitelezését. Például kisiskoláskorban a gyereknek továbbra is segítségre lehet szükségük az ing levételében, a zokni felhúzásában, a fogmosásban, a hajmosásban, az iskolatáska felvételében. Fiatalként komoly nehézséget okozhat, hogy megtanuljanak autót vezetni, vagy egy egyszerű ételt elkészítsenek (pl. tojást sütni, tejbegrízt főzni, zöldséget felvágni, a virágoskertben kapálni).

A diszpraxiával küzdő gyerek a kommunikációja során a beszéd különböző össze-tevőivel kapcsolatos nehézségekkel küzd. Nehéz lehet a számára a szavak képzése vagy a gondolatai kifejezése, nehezen szabályozza a saját hangjának a hangmagasságát és a hangerejét, ami, ha túl hangos vagy túl halk, esetleg túl magas a hangszíne, zavarhatja a környezetét, ezért következményesen nehezebben szerez barátokat, akadályozott a szociális (kapcsolati) területen, a társadalmi beilleszkedésben. A kirekesztettség, az elutasítás, a többiekhez nem tartozás érzése már önmagában is okozhat érzelmi problémákat, de a diszpraxia miatti folyamatos kudarc és a felé közvetített szemrehányások és elégedetlenségek már a korai időszaktól, a szociális kapcsolatok igénye előtti időszakban is akadályozzák az érzelmi és a viselkedésfejlődését. Gyakori, hogy a gyer-mek éretlen módon viselkedik, ami szintén problémákat okozhat a barátságok kialakításában, a másokkal való szocializációban, különösen a már kiskamasz, kamasz, fiatal személyek életében, s nem csak a felnőttek figyelmeztetik állandóan, hanem a kortársai is.

A diszpraxiával küzdő gyerek gyakran csak lassú tempóban tud írni, ami számos osztálytermi, tanórai kihívást okozhat, például az órai jegyzetelésben, vagy a dolgozatok időben való befejezésében legyen az bármilyen tantárgyból. Az otthoni szabadideje is kevesebb, mint a kortársainak, mert az írásbeli házi feladat elkészítése otthon is, a napköziben is elhúzódik, esténként vagy éppen hétvégén kell pótolnia minden elmaradását. A lassúságon és a csúnya külalakon túl a verbális diszpraxiával küzdó gyermeknek gondjai vannak az olvasással és a helyesírással is (I.4.).

\section{Hogyan diagnosztizálják a fejlődési diszpraxiát?}

A különböző szakemberek diagnosztikus munkáját segíteni lehet azzal, ha a szülők elkezdik megfigyelni a gyermeküket, és mindent lejegyeznek, kitérve a gyermek korábbi fejlődésére is, mert a diszpraxia diagnosztizálásához szükséges, hogy a gyermeknél legalább hat hónapon keresztül megfigyelhetôk legyenek a tünetek. De a szülói feljegyzések segítenek azt is felmérni, hogy a gyermek nehézségei akadályozzák-e őt a mindennapi tevékenységekben és a feladatokban. Az előre elkészített szülói megfigyelések a szülő számára is átláthatóbbá teszik a tüneteket, a problémák súlyát, és meggyorsítják a diagnózis felállítását, hiszen nem a szakemberrel való elsô találkozás után kezdi csak el a szülő a megfigyelést és a jegyzetelést.

Nincs egyetlen konkrét teszt (megjegyzés: A hazai és nemzetközi gyakorlatban, a különböző 
szakemberek által használt diagnosztikus tesztek, eszközök bemutatására jelen írásban nem térünk ki) sem annak a meghatározására, hogy egy gyermek diszpraxiás-e. Az orvos, pl. a házi gyermekorvos meg-vizsgálja a gyermeket, hogy kizárjon néhány lehetôséget, majd átirányíthatja egy másik szakemberekhez, elsősorban egy gyermekneurológushoz. A szakorvos megvizsgálja a gyermek izomállapotát, izomtónusát és koordi-nációját és néhány tevékenység közben is megfigyeli, pl. labdába rúgás és eldobása közben vagy amikor fel-lemászik valahova. Egy gyermek esetében a diszpraxia diagnosztizálásához a szakembernek négy fö szempontot kell sorra vennie (I.1.):

- A motoros készségek elmaradnak attól, ami a gyermektől az életkora alapján elvárható

- A motoros készségekben mutatkozó nehézségek akadályozzák a gyermek mindennapi életét és/vagy az iskolai sikerességét.

- A motoros készségek gyengesége nem egy másik idegrendszeri állapot (pl. agyi bénulás) következménye.

- A tünetek az élet korai szakaszában is jelentkeztek már, annak ellenére, hogy az állapotot általában nem diagnosztizálják 5 éves kor elótt

Ha gyermeknél diszpraxia igazolódik be, különböző terápiák segíthetnek az állapot javításában, a tünetek enyhítésében. De a diagnózis szükséges lehet ahhoz is, hogy a gyermek az iskolában is speciális támogatást kaphasson, például több időt egy feladat elkészítéséhez, laptop használatához, vagy éppen szakember által, az iskola keretei között végzett fejlesztő foglálakozáson vehessen részt.

Milyen állapotok kapcsolód(hat)nak a fejlődési diszpraxiához?

Nem szokatlan, hogy a diszpraxiával küzdő gyermeknek más tanulási és figyelmi problémái is vannak, amely „állapottársulást”, a nehézségek halmozódását komorbiditásnak neveznek. A diszpraxiához leggyakrabban a különböző tanulási zavarok (diszlexia, diszgráfia és diszkalkúlia) és a figyelemzavar (hiperaktivitás nélkül vagy hiperaktivitással) szokott társulni. Ma már nem csak a szakemberek, de a szülők is tisztában vannak azzal, hogy a tanulási zavarok három típusa különböző tünetek együttes megfigyelhetőségét jelenti, és hogy milyen nehézségekkel is járhatnak. A diszlexia az olvasásban jelentkező zavaroknak, nehézségeknek olyan különböző tüneteit foglalja össze, amelyek a látott írott szöveg kiolvasása, megértése során tapasztalhatók, s amelyek hatással vannak az írásra és a helyesírásra is. A diszgráfia, mint az írás nehézsége, önmagában is létező probléma, de szinte párhuzamos létezik a diszlexiával. A diszpraxiával közös tünete a betúk, a betúkapcsolatok hibái, a rendezetlen kézírás, az írás lassú tempója. A diszkalkulia a számolás, a számok ismerete és a számokkal végzett múveletek során mutatott nehézségek, zavarok tünetegyüttesének a neve. Ebben az esetben a gyereknek gondjai lehetnek az alapvető matematikai tényekre (pl. $2+2=4)$ való emlékezéssel, ami pl. a számításokat és a mennyiségek becslését nehezíti meg.

A figyelemzavar, aminek két fajtáját kell elkülöníteni, azt, amelyik esetén nem figyelhetô meg hiperaktivitás mint tünet, és az, amelyiknél a hiperaktivitás mint tünet kialakul, és bizony a környezete számára nehéz azt nem észrevenni. Az első, a hiperaktivitás nélküli figyelemzavarral küzdő gyermek problémáját könnyú nem észrevenni, valami mással magyarázni a lemaradását (pl. nem figyel, nem érdekli, vagy éppen hogy nem jók az intellektuális képességei). A figyelem bármilyen (és bármelyik területen jelentkező) zavara megnehezítheti, hogy a gyermek "mozdulatlan” maradhasson (pl. ne fészkelődjön folyamatosan), a koncentrálását, a következmények mérlegelését, és az ösztönösség kontrollálását. A diszpraxiában szen- 
vedő gyermekek körülbelül felének vannak figyelmi problémái is (I.1.).

\section{Hogyan segíthetnek a szakemberek fejlődési diszpraxia kezelésében?}

Szerencsére sok szakember segithet egy gyermek diszpraxiájának a kezelésében. Vannak szakemberek, akik az óvodákban, az iskolákban dolgoznak fóállásban vagy utazó terapeutaként, ami a szülők számára a terápiák megszervezését nagymértékben megkönnyíti és a gyerek számára sem nyúlik hosszúra egy-egy nap.

Többféle terápia segíthet a diszpraxia enyhítésében, amelyekről a gyermekszakorvos, a gyermekneurológus, egy pszichológus, gyógypedagógus, a Pedagógiai Szakszolgálat, de lehet, hogy a gyermek tanítója vagy óvodapedagógusa is tud felvilágosítást adni. A terápiák egyik típusa a logopédiai terápiák, amelyek célzottan elsősorban a gyermek beszédproblémáival, szélesebben a kommunikációjával foglalkozik. Ma már Magyarországon különféle keretek között a szenzomotoros integrációs terápiák többfajtája elérhető. Különböző módszerről kell beszélnünk, de közös mindegyikben, hogy javítják a gyermekek nyelvi, vizuális, mozgáskoordinációs, hallási és figyelmi képességeit, s ezeknek az integrációját, az együttes használatát. A gyerekek egyénileg vagy kiscsoportban, esetleg hometraining formájában mozgásos feladatokat végeznek, amelyek segítenek kialakítani és/vagy megerősíteni a motoros, az érzékszervi és a nyelvi információk integrációját. A gyógypedagógus (esetleg fejlesztőpedagógus) a részképességek és a tanuláshoz szükséges képességek fejlesztését végzik változatos módon, amibe mozgásos feladatok is tartoznak. A szakember a fejlesztés során, amikor a gyermek már nem óvodáskorú, nem kerülheti el, hogy a tananyaggal is foglalkozzon, de olyan módon, hogy a tananyagot mint eszközt használja a képességek fejlesztésére, ami viszont magát a tanulás eredményességét is javítja. A gyógypeda- gógiai fejlesztés során a gyermek megtanulja, hogyan kell egy-egy ismeret- vagy feladattípushoz hozzákezdeni, milyen lépései vannak, hogyan ellenőrizze a munkáját, módszereket, technikákat, algoritmusokat tanul meg, amelyeket új feladat- és problémahelyzetben is tud alkalmazni.

Amikor a gyermeknél diszpraxiát diagnosztizálnak, és az illetékes Pedagógiai Szakszolgálat a vizsgálatai alapján sajátos nevelési igényú (esetleg beilleszkedési-, tanulási-, magatartási nehézséggel küzdő) tanulónak minősíti, akkor az iskola, pontosabban a gyermek fejlesztésére kijelölt szakember(ek) egyéni fejlesztési tervet dolgoz(nak) ki. A Szakszolgálat javaslata alapján az iskola vezetóje például mentesítheti a tanulót a testnevelés óra bizonyos feladatai alól vagy a testnevelótanárnak módosítania kell egyes feladatokat a tanuló számára. Ugynakkor az iskola, a gyermeket ismerve, diagnózis nélkül is számos dolgot megtehet annak érdekében, hogy a tanulónak hatékony segítséget nyújtson a helyi lehetőségek keretében.

\section{Mit tehetünk otthon fejlődési diszpraxia esetén?}

Sokat tehetnek maguk a szülők is a gyermekük diszpraxiájának az enyhítésé érdekében. A diszpraxiáról keveset és kevesen tudnak, kevésbé ismert, mint például a diszlexia vagy a figyelemzavar. Ezért nagy az esélye annak, hogy a szülők, a barátok és még a tanárok sem értik meg gyermek nehézségeit, küzdelmeit. Az információk megosztása azokkal, akikkel a gyerek sokat van, segít abban, hogy a gyermek megkapja a szükséges megértést, a pedagógiai vagy speciális támogatást, vagy egyszerúen csak helyesen értelmezzék a gyermek tüneteit és a viselkedését.

A szülők azzal, ha a gyermeküket biztatják az olyan játékokra, tevékenységekre, amelyek testmozgást, a motoros képességek használatát igénylik, legyen az valamilyen sport, vagy túrázás, barkácsolás, segítség a házimunkában, támogathat- 
ják a fejlődését. Függetlenül attól, hogy úszásról vagy egyszerû bújócskáról beszélünk, jó, ha a diszpraxiával küzdő gyerek sokat mozog, mert életkorukból és a szocializációs fejlődésükből fakadóan a mozgás segítheti a más gyerekekkel, a kortársakkal való kapcsolatok kiépítését és fenntartását is.

A puzzle játékokban sokkal több rejlik, mint amit általában gondolunk az ilyen típusú játékokban. Intenziven segíthetnek a vizuális és a térbeli észlelésben, a finom motoros készségek fejlesztésében, a kitartásban, de csakis a klasszikus (kézbe vehető) fajtái. Fontos, hogy a gyermek ne számítógépen játssza, hanem a valóságban, a kezében fogva és forgatva. A képek kirakása akár családi vagy gyerekszülő elfoglaltság is lehet, amikor a szülő mintát ad ahhoz, hogy hogyan kell egy „rejtvényt” megoldani, kitartóan próbálkozni.

A babzsák, a zoknigombóc, a kisebb plüssállatok, stb. mind lehetóséget adnak arra, hogy játék közben fejlődjön a kéz-szem koordináció, mert ezeket el lehet dobni vagy kapni, méretükhöz, súlyukhoz, tapintásukhoz kell alkalmazkodni közben.

A különböző kiképzésú ceruzák, tollak, ceruzafogók közül próbálgatások, használat közben választhatja ki a gyermek, hogy számára melyik a legkényelmesebb. A diszpraxiás gyermekeknek érdemes megvenni a színes, csillogó, éppen divatos íróeszközöket, hogy legyen kedve írni velük.

A nagyobb (felső tagozatos) gyerekek gyakorolhatják a számítógép használatát, az írást a billentyúzet segítségével. Azonban nem szabad elfelejteni, hogy a billentyűzet gyors és megfelelő használata egy készség, amelyet meg kell tanulni és sokat kell gyakorolni, ami a diszpraxiások esetében az átlagnál több gyakorlást és kitartást igényel. Tehát az olvashatatlan kézírás gépírással való kiváltásához hosszú út vezethet. A kézíráshoz vagy akár a számítógép billentyúzetének a használatához szükséges kézizmokat lehet erősíteni a különféle gyurmákkal, a stesszlabda szorításával. A gyermeknek sokáig szüksége lehet segítségre az önkiszol- gálásban és a mindennapi tevékenységekben, még akkor is, amikor a kortársaik már önállóak azokban. Tudva ezt, amikor végre egyedül meg tud csinálni valamit, fontos a dicséret, a pozitív visszajelzés a számára. De kapjon dicséretet és/vagy jutalmat akkor is, amikor új feladatot, tevékenységet kipróbál, tehát észre kell venni a legkisebb előrelépést, erőfeszítést is, mert ezzel erősödik a gyermek önbizalma, javul az önértékelése, pozitívabb lesz az énképe. Szükséges a sok dicséret és biztatás, a kisebb sikerélmények biztosítása, mert nem szabad elfelejtenünk, hogy a diszpraxia bosszantó és frusztráló lehet a gyermeknek is, nem csak a környezetének.

\section{Zárszó}

„Mindig nagyon rendetlen a ruhája, a környezete. Nem szereti a labdát. Nem is szokott futkosni, felmászni ide-oda, mint a testvére, soha nem is tette, mint a testvére. Nem tud hintázni sem, pedig már iskolás, már harmadik éve tanítjuk biciklizni, szerencse, hogy bérházban lakunk így ritkábban kerül elő a bicikli. Így kevesebbet sír vagy dühöng miatta. A háromkerekú rollerrel is képes felborulni. A testnevelés órák reggelén nem akar iskolába menni, azt mondja, hogy fáj a hasa vagy a feje. Amikor az apjával birkóznak, mindig sírás a vége, van, hogy az apja sérül meg. Rendetlen a táskája, a füzete és a könyve gyưrött, pedig már mindent kitaláltam. Rondán, olvashatatlanul ír, de azt is lassan, mintha nem tudná a betúket, pedig tudja. Mindent elfelejt, ott felejt, állandóan mondani kell neki, mi-kor mi következik. És közben ő egy nagyon szerethetô, sok szeretetet adó, elmélyülni tudó gyerek. Általában nagyon infantilisan viselkedik, néha meg egészen felnőttes gondolatai vannak, és olyan érettnek tünik, amikor a problémáiról beszélgetünk.” (egy szülő)

A diszpraxiás gyermek nevelése sok türelmet és energiát igényel. De ezzel a problémával nincs 
egyedül, s nem csak a szakemberekre gondolunk most, hanem azokra a szülőkre is, akiknek a gyereke hasonló gondokkal küzd. A szülők megtanulhatják egymástól, hogy sokat tehetnek a gyermekük nehézségeinek az enyhítéséért, de nem kell mindent egyszerre csinálni és azonnal elérni. Ha egyszerre túl sok célt tûzünk ki magunk és a gyerek elé, s emiatt túl sok új stratégiát próbálunk követni, nehéz lehet megtalálni, melyik működik a legjobban. Adjunk időt magunknak, a gyermeknek és egy-egy módszernek, stratégiának, de úgy, hogy közben ne csak a „feladat” töltse ki az életünket, hanem szórakozzunk is együtt, és legyenek olyan időszakok (egy napon belül is), amikor a gyermek a saját szintjén és választása alapján végzi a tevékenységeket.

\section{Irodalom}

Barnhart RC, Davenport MJ, Epps SB, Nordquist VM (2003). Developmental coordination disorder. Physical Therapy, (8) 722-31.

Blank R, Smits-Engelsman B, Polatajko H, Wilson P (2012). European Academy for Childhood Disability (EACD): recommendations on the definition, diagnosis and intervention of developmental coordination disorder. Developmental Medicine and Child Neurology, (1) 54-93. DOI: 10.1111 / j.1469-8749.2011.04171.x

Dewey, D. (1995). What is developmental dyspraxia. Brain and Cognition, (3), 254-274. DOI: 10.1006 / brcg. 1995.1281

Fehérné Kovács Zsuzsanna, Kas Bence, Sósné Pintye Mária (é.n.): Szempontok a nyelv-és beszédfejlódési zavarok szüréséhez és állapotmegismeréséher: Családbarát Ország Nonprofit Kft., Budapest. (In Press)

Gibbs, J., Appleton, J., \& Appleton, R. (2007): Dyspraxia or developmental coordination disorder? Unravelling the enigma. Archives of Disease in Childhood. (92) 534-539. DOI: $10.1136 /$ adc. 2005.088054
Henderson, SE, \& Henderson, L (2003): Towards an understanding of developmental coordination disorder: terminological and diagnostic issues. Neural Plasticity (10) 1-13. DOI: $10.1155 /$ NP.2003.1

Huba, J. (2011): Psæichomotoros fejlödés és fejles₹tés. Logopédia Kiadó, Budapest

Miyahara, M., \& Möbs, I. (1995): Developmental dyspraxia and developmental coordination disorder. Neuropsychology Review, (4), 245-268. DOI: 10.1007 / BF02214648

Polajko, Fox \& Missiuna (1995): An international consensus on children with developmental ccordination disorder. Canadian Journal of Occupational Therapy (62) 3-6. DOI: 10.1177/000841749506200101

Roy, D. \& Dock, C. (2013): Dyspraxia, Delinquents and Drama Journal of Education in the Dramatic Arts, (2) 26-31.

Szvatkó Anna (szerk) (2016): Billenések Tanulmányok a dinamikus szenzoros integrációs terápia köréböl, Oriold és Társai Kft.

Zwicker. J.G., Missiuna, C., Harris, S.R. \& Boyd, L.A. (2012): Developmental coordination disorder: a review and update. European Journal of Paediatric Neurology. (6) 573-81. DOI: $10.1016 /$ j.ejpn.2012.05.005

\section{Internetes források}

I.1. American Psychiatric Association. (2013): Diagnostic and statistical manual of mental disorders (DSMV) (5th ed.). Washington, DC. https://books.google.hu/books?hl=hu\&lr=\&id =-JivBAAAQBAJ\&oi=fnd\&pg= PT18\&dq =Diagnostic + and + statistical + manual +of + mental+disorders+ (DSM-

V $)+(5$ th + ed.\&ots $=$ ceVT05OGs7\&sig $=z N Z n E$ $\mathrm{XKXBJisWy-}$

WEebqh6jPb9mg\&redir_esc $=\mathrm{y} \#_{\mathrm{v}}=$ onepage\&q $=$ Diagnostic $\% 20$ and $\% 20$ statistical $\% 20$ manual $\% 20$ of $\% 20$ mental $\% 20$ disorders $\% 20$ (DSM- 
V)\%20(5th\%20ed.\&f=false (letöltés: 2019. 06. 21.)

I.2. NINDS Developmental Dyspraxia Information Page." NINDS.nih.gov. National Institute of Neurological Disorders and Stroke. Web. http://www.ninds.nih.gov/disorders/dyspraxia Ldyspraxia.htm (letöltés: 2019. 11. 07.)

I.3. Causes of Dyspraxia. NHS.uk. National Health Service
http://www.nhs.uk/Conditions/Dyspraxia(childhood)/Pages/Causes.aspx (letöltés: 2019. 11. 07.)

I.4. Reading and Spelling. Dyspraxiafoundation.org.uk. Dyspraxia Foundation. Web. http://www.dyspraxiafoundation.org.uk/aboutdyspraxia/reading-spelling/ (letöltés: 2019. 11. 07.) 